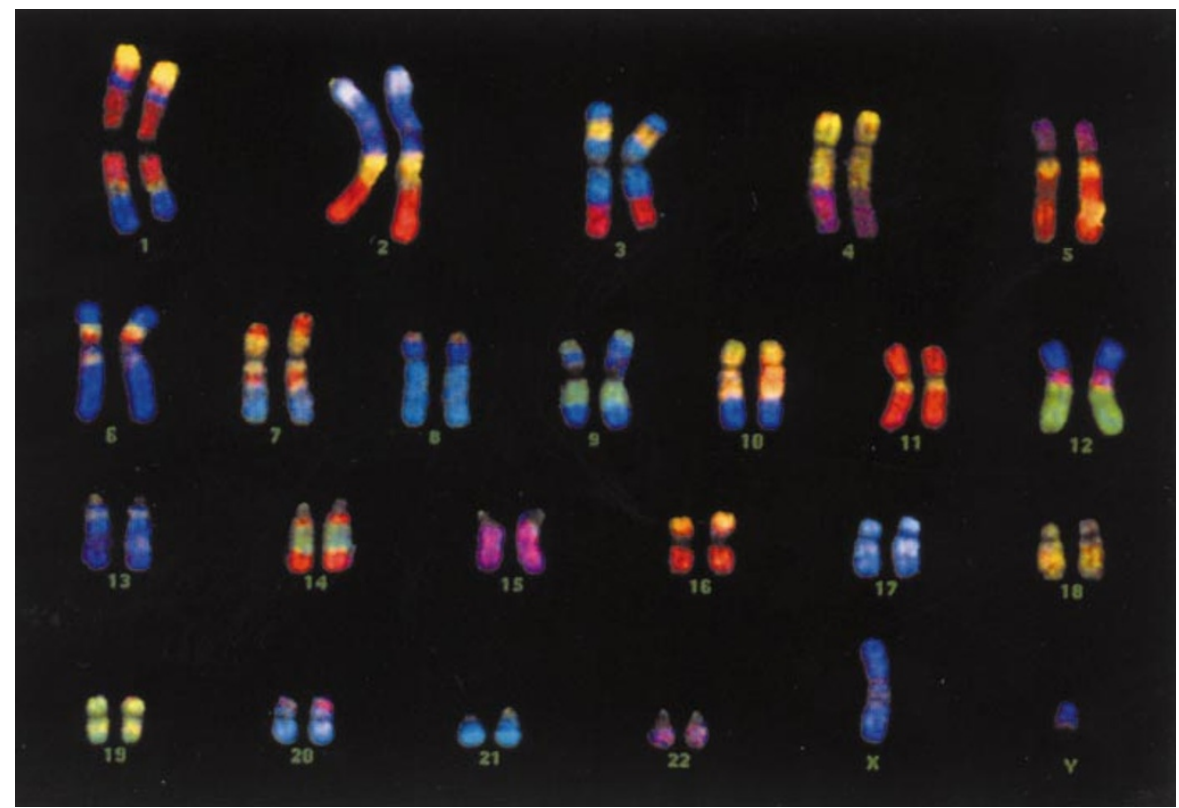

Chapter and verse: the entire contents of the 23 human chromosomes should soon be known.

of the immune response, such topics would have been my natural choice for chromosome 6. But immunology, in spite of its enormous interest and dramatic development, hardly gets a mention, even in the discussion of asthma, and the only reference to the HLA system is in relation to the rather questionable data on mating preferences. Ridley's chromosome 6 is devoted to the somewhat flimsy evidence for a gene with a possible influence on IQ.

There are some good chapters. The relationship between the apoE lipoprotein gene and Alzheimer's disease is well told and the chapter on BSE is also good. Ridley even mentions James Parry, the geneticist in Oxford whose sheep pedigrees told the correct story about scrapie, as he explained to me when I first came to Oxford in 1970, and which no one believed. A good chapter on eugenics is seriously marred by the fact that it draws the analogy between screening for Down's syndrome and Nazism. Even negative eugenics is hardly applicable to Down's syndrome, and the importance of doing genetic screening only if benefit can be derived from it is hardly mentioned.

Historical treatments of scientific discoveries are a good vehicle for presenting the underlying science, but not when they are as abbreviated and distorted as they often are in Genome. There were, for example, several co-discoverers of the $p 53$ gene; and the molecular biology of prions was uncovered by Charles Weissmann and his colleagues. The story of Gregor Mendel's discoveries is described as though they appeared from nowhere, and ignores the evidence that they were stimulated by his abbot's interest in uncovering the basis for the animal and plant breeding used in the monastery's farms. It was the theoretical physicist
George Gamow, not Francis Crick, who first suggested codes relating DNA to protein. I still remember when, as a young mathematical geneticist, I sought Crick's advice about problems I might investigate in molecular biology, and he suggested that I explore the mathematics of overlapping codes. Fortunately and correctly, I did not see how my mathematics could help to provide a solution to the coding problem, which eventually came entirely from experimental approaches.

Style is, I suppose, a matter of personal preference. "Now I tell you again Dear Reader" somehow does not, to my mind, match the topic of 'genome'. Suddenly, towards the middle of the book, we are told "the human genome project is founded upon a fallacy"! He has clearly not yet explained the importance of human variation, which underlies any explanation, for example, of the balance between nature and nurture. Perhaps it is this he is referring to when he says, "the tension between universal characteristics of the human race and particular features of individuals is what the genome is all about". There is also the occasional strange, throwaway sentence: "But then judges were never very good at science" seems a remarkably injudicious comment, and I wonder on what basis he makes this extraordinary suggestion.

Ridley has written well in the past on evolutionary topics, and is clearly capable of writing in a stimulating way for the general reader. Perhaps in future he would do best to stick to topics involving evolutionary ideas, where he is most at home. If this book kindles an interest in the genome and what can be found out using modern genetic approaches, then perhaps it is doing a service. But if you want a serious and challenging discussion of what genetics and the genome can tell us about humans, I am afraid you must look elsewhere.

Walter Bodmer is at the Cancer and Immunogenetics Laboratory, Imperial Cancer Research Fund, Institute of Molecular Medicine, Oxford OX3 9DS, UK.

\section{Darwin's evolution}

\section{Almost Like a Whale: The Origin of Species, Updated \\ by Steve Jones \\ Doubleday: 1999. 402 pp. $£ 20$ \\ Mark Pagel}

Gilbert White, writing in 1773 in his Natural History and Antiquities of Selborne, understood why owls have unusually "soft and pliant" feathers on the tips of their wings, but he could not begin to comprehend why "some females of the brute creation ... devour their young", adding "I leave [this] to abler philosophers than myself to determine". Writing a century later, a biologist gave the answer, "these practices appear to have originated in savages recognising the difficulty, or rather the impossibility of supporting all the infants that are born".

The biologist was Charles Darwin, whose Origin of Species had by the time of this quote already earned him fame and opprobrium in various quarters. The reason was not that Darwin could explain better than others the functions of the diverse traits and characteristics of animals, but that he had offered a mechanistic account of how animals, including humans, come by those traits. That mechanism he called 'natural selection', and so radical were Darwin's views that much of the Origin can be seen as a highly selfconscious defence of his claims for its near-exclusive role in shaping life. Every page carries a sense of Darwin's disquiet that, at least for the reader, some insuperable challenge to natural selection will arise: Darwin repeatedly reminds us of the truth of "my theory", or the plausibility of "my account".

By all reasonable measures, the theory has given a good account of itself. Academic journals, books, newspapers, radio and television brim with 'darwinian' (this journal now insists on the lower case in the adjective) investigations of this or that, and they are not limited to biology. Economics, politics, philosophy, linguistics, psychology, medicine and other fields have succumbed to the darwinian juggernaut. Novelists are asked to debate its merits. Sophistication shows up where least expected: the Kansas Board of Education creationists who recently banned Darwin from Kansas schools accept the reality of microevolution (evolution within species); they just don't like macroevolution 


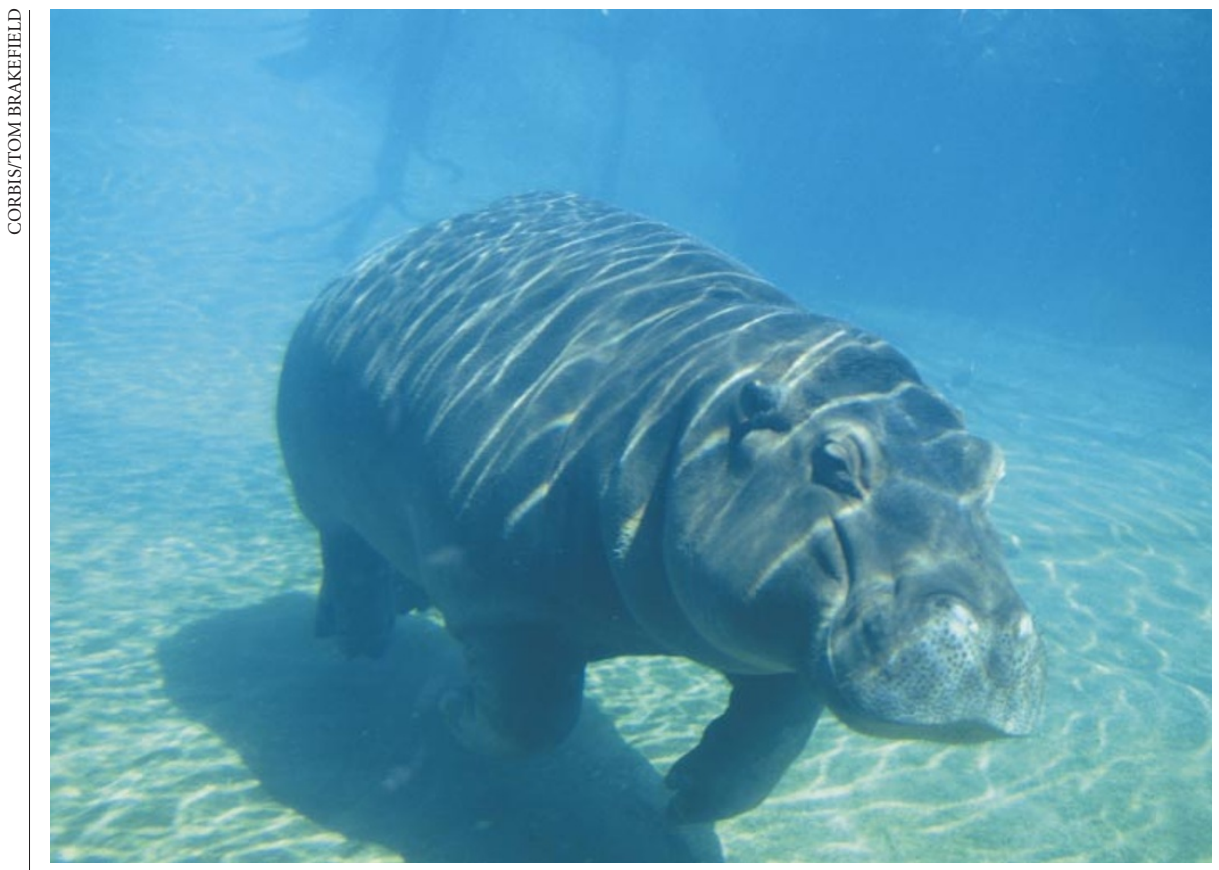

Almost like a whale: the hippopotamus is the whale's closest living relative.

(one species descending from another). Indeed, so conventional has Darwin become that even the Pope accepts the reality of evolution, although he shrewdly insists that souls are outside its reach.

Steve Jones equally shrewdly realizes that all this makes Origin of Species a good candidate for the book of the millennium - a view others share. It may come as a surprise, then, to learn that he has chosen to rewrite it. Is this the scientific rationalist's variation on blasphemy? Jones thinks not, suggesting that, although no one ever put the case for 'evolution' better than Darwin (ironically, Darwin avoided that word, using it only once in the Origin), the facts in the Origin "are those of a century and a half ago and leave many gaps before its case can be considered proven". Reverently, Jones retains and uses as his own framework Darwin's chapter titles, chapter summaries, lists of chapter contents and, curiously, all of Darwin's final chapter. The title is his own, although it, too, derives from a line in the Origin.

Jones's opening remarks cite the familiar refrain of the "100 million Americans" who believe that "God created man pretty much in his present form at one time during the last ten thousand years". In fact, even this represents progress for the theory: these same 100 million people have been quoted since I was a boy, when they made up nearly 50 per cent of the US population. Now there are something like 280 million Americans.

Most of the book's introductory chapter, however, is devoted to the AIDS virus. Jones observes that "the human immunodeficiency virus contains in its brief history the entire argument of The Origin of Species". And so it does. Research on HIV reveals its struggle for existence, the action of natural selection, its

geographical spread and descent with modification. How much more about evolution and adaptation must be known if other organisms are included? In succeeding chapters, Jones moves on to these other organisms, and draws on a prodigious inventory of facts to support Darwin's original musings on 'variation under domestication', 'difficulties of the theory', the 'imperfection of the geological record', 'hybridism' and more.

Imagine Darwin's delight had he known that hippopotamuses are the closest living relatives to the whales, or that Arctic and Antarctic fishes have independently evolved anti-freeze, or that some insects got their wings from the gills of other insects. Where Darwin, of course, had no knowledge of or access to genetic information, Jones reports many of the latest charms of evolutionary genetics, such as horizontal gene transfer, selfish DNA and genome mapping projects. All this is reported in his staccato style, suitable for the general reader and yet informative for the specialist. He is seldom more than a paragraph away from some amusing or thought-provoking anecdote: the allegations about George Spencer and a one-eyed pig are memorable.

Jones is sceptical about much of the work that applies principles of natural selection to understanding human social evolution and behaviour: human sociobiology. Darwin, whose The Descent of Man - and Selection in Relation to Sex remains startlingly bold and perspicacious in doing just that, would not, I think, approve. True, some human sociobiological studies border on the crude and offensive. Others, however, are producing some of the most challenging and stimulating work in evolutionary biology. Humans are to some extent the final frontier, always until now pro- tected from the vulgar apparatus of biological evolution by intelligence and cultural innovation. But demonstrations that cultural practices, including wealth inheritance and marital systems, family size and differential investment in children, are explicable on darwinian grounds have demolished the view of humans as above the fray.

Nevertheless, Jones remains one of our most effective commentators and writers on science. Almost Like a Whale, at around 400 thick pages, is almost like a whale to carry around. But it repays the effort. This 'Origin of Species - Revised Edition' may lack the sense of danger and discovery of its predecessor, and the radicalism has been replaced by a presumption of the truth of natural selection. Yet Jones succeeds impressively in his desire to bring us up to date on the facts of evolution: to read this book is to see in one place much of the sweep and grandeur of evolution by natural selection.

Mark Pagel is at the School of Animal and Microbial Sciences, University of Reading, Whiteknights, Reading RG6 6AJ, UK.

\section{Coelacanth à la Marseillaise}

\section{A Fish Caught in Time: The Search for the Coelacanth \\ by Samantha Weinberg \\ Fourth Estate: 1999. 239 pp. $£ 13.99$ \\ Philippe Janvier}

In December 1938, the first living coelacanth (Latimeria chalumnae) to become known to science was accidentally caught near East London in South Africa. Coelacanths were thought to have been extinct for 70 million years - since the late Cretaceous - hence the sensational impact of this discovery of a 'living fossil'. But, in addition to this astonishing survival, the coelacanth revealed the anatomy of the soft tissues of 'crossopterygian' fishes, thought to have been forerunners of the four-legged vertebrates, or tetrapods. Therefore, it raised considerable interest among evolutionary biologists and palaeontologists. Samantha Weinberg's book describes the history of the discovery of the living coelacanth, and the lives of the women and men involved in it.

Several books have been published previously on the story of the Comoran coelacanth, including Old Fourlegs by J. L. B. Smith (Longmans, 1956), who first described the fish and named it after its discoverer, Marjorie Courtenay-Latimer. But Weinberg's book also includes the account of the recent discovery of the Indonesian coelacanth. In her book, both discoveries sound like detec- 